\title{
FAKTOR YANG MEMPENGARUHI INTERNET FINANCIAL REPORTING (IFR) PADA PERUSAHAAN MANUFAKTUR SUB SEKTOR FOOD AND BAVERAGE YANG TERDAFTAR DI BEI 2015-2019
}

\author{
Arfian Candra Saputra ${ }^{1}$ \\ Endang Masitoh ${ }^{2}$ \\ Yuli Chomsatu Samrotun ${ }^{3}$ \\ ${ }^{1}$ Falkultas Ekonomi, Universitas Islam Batik Surakarta \\ Email : Arfiancandra20@gmail.com \\ ${ }^{2}$ Falkultas Ekonomi, Universitas Islam Batik Surakarta \\ Email : yunmasitoh@yahoo.com \\ ${ }^{2}$ Falkultas Ekonomi, Universitas Islam Batik Surakarta \\ Email :Chom_satoe@gmail.com
}

\begin{abstract}
This research was conducted in order to obtain empirical evidence about the effect of firm size, profitability, liquidity, and leverage on internet financial reporting (IFR). Samples taken in this study are manufacturing companies in the food and beverage sub-sector which are listed on the IDX 2015-2019. Sources of data used are secondary data, in processing this research data using multiple linear regression method. The sample in this study was obtained by purposive sampling method, in order to get 10 companies that meet the criteria and the data obtained in the study were 50 data. The results showed that firm size, profitability, and liquidity had an effect on internet financial reporting (IFR), while leverage had no effect on internet financial reporting (IFR).
\end{abstract}

Keywords: IFR, Size, Profitability, Liquidity, Laverage.

\section{PENDAHULUAN}

Perekonomian global saat ini secara tidak langsung berimbas bagi perekonomian di Indonesia. Keadaan politik dalam negeri juga mempengaruhi perekonomian. perkembangan teknologi yang semakin canggih, internet telah banyak digunakan oleh berbagai kalangan baik muda maupun tua. Kalangan investorpun juga menggunakan Internet untuk mencari informasi tentang perusahaan perusahaan yang akan di jadikan wadah untuk investasi. Internet merupakan situs penyedia informasi perusahaan bagi masyarakat secara rinci dan cepat, didalam internet menawarkan suatu bentuk unik pengungkapan laporan keuangan (Abdelsalam, El-Masry, \& Ahmed, 2008). Dengan perkembangan internet yang semakin canggih timbullah media corporate internet reporting (CIR) atau internet financial reporting (IFR). Media ini berisikan tentang laporan keuangan suatu perusahaan yang diungkapkan dalam bentuk website perusahaan yang sifatnya sukarela dan telah banyak perusahaan yang melakukan hal ini.

(Ettredge, Richardson, \& Scholz, 2001) menyatakan bahwa IFR membantu perusahaan dalam menyebarluaskan informasi mengenai keunggulan perusahaan yang merupakan sinyal positif perusahaan untuk menarik investor. Media informasi untuk pengambilan keputusan diperlukan dalam menjalankan peran akuntansi di pasar uang dan pasar modal. Fungsi informasi akuntansi dalam hal ini adalah media sebagai agen dalam memberikan informasi kepada principal mengenai pengelolaan investasi pemilik.

Bagi investor laporan keuangan perusahaan yang terbit di internet atau website merupakan bentuk media komunikasi mereka dengan perusahaan sebagai bahan pertimbangan mereka. Dengan adanya pelaporan keuangan tersebut dapat mempermudah para investor dalam menilai kinerja perusahaan. Dengan menyajikan informasi keuangan perusahaan menggunakan IFR, perusahaan dapat menghemat biaya serta dapat menjangkau para pengguna secara luas (Akbar, 2014). Hal tersebutlah yang mendorong perusahaan untuk menerapkan praktik IFR. Meskipun begitu, praktik IFR belum banyak digunakan oleh beberapa perusahaan (Xiao, Yang, \& C, 2004). Dalam penerapan IFR banyak faktor yang berpengaruh dalam perusahaan.

Berdasarkan penelitian yang telah di lakukan (Diatmika \& Yadnyana, 2017), memperlihatkan bahwa variabel ukuran perusahaan, leverage dan penawaran saham baru berpengaruh terhadap pengungkapan pelaporan keuangan melalui website. Sedangkan variabel profitabilitas, reputasi auditor dan kepemilikan publik tidak berpengaruh terhadap pengungkapan pelaporan keuangan melalui website. Penelitian sejenis di lakukan oleh (Gat, 2016), memperoleh hasil bahwa variabel Profitabilitas, Likuiditas, leverage tidak berpengaruh terhadap IFR. Sedangkan variabel Ukuran berpengaruh terhadap IFR. 
Penelitian yang dilakukan (Putri \& Azizah, 2019), memperoleh hasil bahwa variabel ukuran perusahaan, leverage, dan profitabilitas berpengaruh terhadap laporan keuangan perusahaan melalui internet/Internet Financial Reporting. Namun dari penelitian- penelitian yang telah dilakukan masih menunjukkan adanya ketidak konsistenan beberapa faktor yang mempengaruhi Internet Financial Reporting (IFR). Penelitian ini berfokus pada variabel ukuran perusahaan, profitabilitas, likuiditas dan leverage.

Rumusan masalah pada penelitian ini adalah "apakah variabel ukuran perusahaan, profitabilitas, likuiditas dan leverage mempunyai pempengaruh pada Internet Financial Reporting (IFR) ?”. Penelitian ini bertujuan untuk menguji dan menganalisis variabel ukuran perusahaan, profitabilitas, likuiditas dan leverage terhadap Internet Financial Reporting (IFR).

\section{TINJAUAN PUSTAKA}

\section{Teori Keagenan (Agency theory)}

Agency theory adalah teori yang menyatakan adanya perbedaan kepentingan antara principal dan agen, dimana stakeholder berperan sebagai prinsipal dan management perusahaan sebagai agen. Jansen Mackling menyatakan adanya hubungan kerja antara principal dan agen untuk memfasilitasi pelayanan bagi mereka dengan memberikan wewenang kepada agen dalam pengambilan keputusan (Gat, 2016).

\section{Konsep Dasar \\ Internet Financial Reporting (IFR)}

Internet Financial Reporting merupakan suatu tindakan yang dilakukan perusahaan untuk manyampaikan laporan keuangannya kepada para pengguna dengan cara melalui internet atau website yang dimiliki perusahaan (Kusumawardani, 2011). Pelaporan informasi keuangan melalui internet (internet financial reporting) merupakan salah satu contoh bentuk pengungkapan sukarela. Adanya laporan melaui internet, informasi tentang perusahaan akan tersebar secara luas, cepat dan murah. Dalam Penelitian (Heong Yap \& Saleh, 2011) menyebutkan adanya faktor penting bagi perusahaan dalam penerapan IFR yaitu dapat mempublikasikan laporan keuangan perusahaan secara lebih transparant, perusahaan dapat mempromosikan produk dan memberikan pelayanan bagi konsumen secara gratis, dan perusahaan yang memberikan informasi melalui website akan mendapatkan kepercayaan yang baik dalam mempromosikan transparansi yang lebih luas.

\section{Ukuran Perusahaan}

Menurut (Oyelere, Laswad, \& R, 2003) ukuran perusahaan adalah skala besar kecilnya perusahaan yang dapat diklasifikasikan berdasarkan berbagai cara antara lain dengan ukuran pendapatan, total asset dan total ekuitas. Melalui ketiga pendekatan ini dapat dijadikan tolak ukur seberapa besar ukuran perusahaan tersebut. Perusahaan yang relatife besar memiliki tanggung jawab mempublikasikan laporan keuangan kepada shareholders yang disampaikan oleh agency cost (Prasetya \& Irwandi, 2012). Agency cost merupakan biaya publikasi laporan keuangan, yang terdiri dari biaya cetak dan biaya pengiriman kepada pihak- pihak yang berkepentingan (Oyelere, Laswad, \& R, 2003). Usaha mengurangi biaya agency cost yaitu dengan menerapkan praktik IFR dalam mempublikasikan laporan keuangan. Semakin besar perusahaan maka semakin tinggi pula kelangsungan usaha suatu perusahaan dalam meningktkan kinerja keuangan, sehingga dapat dilihat dari banyaknya jumlah peredaran saham. Ukuran perusahaan dinyatakan dengan total asset, jika semakin besar total asset perusahaan maka akan semakin besar pula ukuran perusahaan tersebut (Harahap, 2013).

\section{Profitabilitas}

Profitabilitas adalah rasio yang memperlihatkan sejauh manakah perusahaan mengelola modal sendiri secara efektif mengukur tingkat keuntungan dari investasi yang telah dilakukan pemilik modal (Hermuningsih, 2013). Menurut (Kusumajaya, 2011) Return on equity (ROE) merupakan alat analisis untuk mengukur sejauh mana kemampuan perusahaan dalam menghasilkan keuntungan bagi pemilik saham atas modal yang telah mereka investasikan. ROE adalah faktor yang memberikan kebebasan dan fleksibilitas kepada manajemen untuk melakukan dan mengungkapkan kepada pemegang saham program tanggung jawab social secara lebih luas. Semakin besar profit perusahaan maka akan semakin besar kemungkinan perusahaan melakukan praktik IFR sebagai salah satu sarana untuk menyebar luaskan goodnews. Tingkat profitabilitas yang konsisten akan mampu bertahan dalam bisnisnya dan mampu mencerminkan kinerja manajemen yang baik. Faktor ini dapat menarik pertimbangan bagi investor dalam pengambilan keputusan, selain profitabilitas yang tinggi investor akan memperhatikan efektivitas kinerja manajemen dalam mengelola sumber dana perusahaan. 


\section{Likuiditas}

Likuiditas menggambarkan kemampuan perusahaan dalam memenuhi kewajiban jangka pendeknya (Lestari \& Chariri, 2009). Perusahaan dengan likuiditas tinggi akan memiliki risiko yang relative kecil sehingga kreditur merasa yakin dalam memberikan pinjaman kepada perusahaan dan investor akan tertarik untuk mengnvestasikan dananya ke perusahaan tersebut karena investor yakin bahwa perusahaan mampu bertahan. Perusahaan dengan likuiditas tinggi akan dilihat oleh publik, sehingga perusahaan tersebut akan melaorkan kondisi keuangannya dengan lengkap, salah satunya dengan melalukan praktik IFR (Internet Financial Reporting). Variabel independen penelitian ini yaitu likuiditas. Dalam penelitian ini likuiditas diukur dengan menggunakan curren ratio, yaitu aktiva lancar di bagi dengan hutang lancar. Rasio ini menggambarkan besarnya asset lancar perusahaan yang dapat dicairkan dengan perputaran kurang dari satu tahun daripada kewajiban lancar yang dimilikinya (Pranoto, 2015).

\section{Leverage}

Leverage dihitung untuk tujuan mengetahui seberapa besar asset perusahaan yang dibiayai oleh hutang perusahaan, rasio leverage menggambarkan kemampuan perusahaan dalam pembiayaan operasionalnya menggunakan dana yang berasal dari pinjaman pihak luar perusahaan (Harahap, Analisis Kritis Laporan Keuangan, 2007). Perusahaan dengan tingkat leverage yang tinggi akan mendorong pihak manajemen untuk menggunakan IFR (Internet Financian Reporting) dalam menyebarluaskan informasi positif perusahaaan sehingga inverstor tidak terlalu fokus pada leverage perusahaan yang tinggi (Lestari \& Chariri, 2009). Paperbased reporting dapat digunakan sebagai media penyebarluasan informasi yang banyak bagi perusahaan serta dapat digunakan sebagai media pelaporan keuangan.

Penelitian terkait Pengaruh Ukuran Perusahaan, Leverage Dan Profitabilitas Terhadap Pelaporan Keuangan Melalui Internet (Internet Financial Reporting) yang dilakukan oleh (Putri \& Azizah, 2019) dengan menggunakan metode analisis regresi linear berganda hasilnya menunjukkan bahwa variabel ukuran perusahaan, leverage, dan profitabilitas berpengaruh terhadap pelaporan keuangan melalui internet (Internet Financial Reporting). Menurut (Oyelere \& Kuruppu, 2016) yang melakukan penelitian tentang faktor yang mempengaruhi Internet Financial Reporting di 132 perusahaan yang terdaftar di Bursa Efek Abu Dhabi dan Pasar Keuangan Dubai, Hasil menunjukkan bahwa ukuran dan leverage perusahaan berpengaruh terhadap IFR. Namun, profitabilitas, industri dan likuiditas tidak tidak berpengaruh terhadap IFR.

\section{Kerangka Pemikiran}

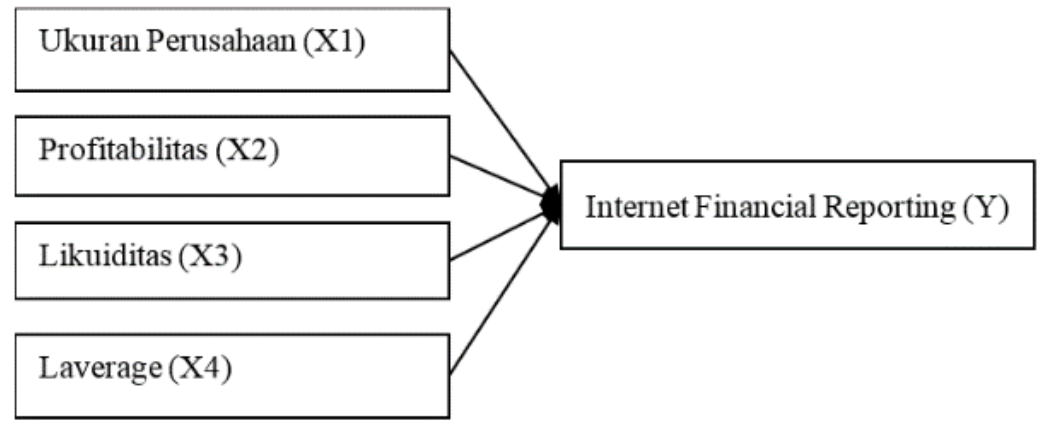

Gambar 1

Kerangka Pemikiran

Pengaruh Ukuran Perusahaan terhadap Internet Financial Reporting (IFR)

Pengungkapan informasi yang lebih banyak akan meningkatkan agency cost perusahaan. Perusahaan yang berskala besar memiliki kemungkinan melakukan praktik Internet Financial Reporting (IFR) dalam mempublikasikan laporan keuangan dan non keuangan hal ini dilakukan untuk mengurangi besarnya Agency Cost. Penelitian yang dilakukan oleh (Gat, 2016) menyatakan bahwa Ukuran Perusahan berpengaruh terhadap Internet Financial Reporting (IFR). Hasil penelitian tersebut selaras dengan hasil penelitian yang dilakukan oleh Aboutera \& Hussein (2017). Berdasarkan uraian di atas, hipotesis yang diajukan sebagai berikut :

\section{$\mathbf{H}_{1}$ : Ukuran Perusahaan berpengaruh terhadap Internet Financial Reporting (IFR).}


Pengaruh Profitabilitas terhadap Internet Financial Reporting (IFR)

Aly,et al (2010) menemukan bahwa terdapat pengaruh yang positif antara profitabilitas (ROE) dengan Internet Financial Reporting. Hal ini mengindikasikan bahwa perusahaan yang profitable akan menggambarkan pengelolaan manajemen yang baik sehingga akan mengungkapkan lebih banyak informasi, karena dengan adanya sumber keuangan yang lebih besar dari perputaran aktiva perusahaan, mendukung hubungan positif tingkat pengungkapan sukarela (IFR) dengan profitabilitas. Dalam penelitian (Hidayah, 2017) menyatakan bahwa Profitabilitas berpengaruh terhadap Internet Financial Reporting (IFR). Berdasarkan uraian diatas, maka hipotesis yang dibangun dalam penelitian ini adalah:

\section{$\mathbf{H}_{2}$ : Profitabilitas berpengaruh terhadap Internet Financial Reporting (IFR).}

Pengaruh Likuiditas terhadap Internet Financial Reporting (IFR)

Perusahaan dengan likuiditas yang tinggi akan mempublikasi laporan keuangan selengkap mungkin, yaitu dengan cara melakukan praktik Internet Financial Reporting (IFR) (Lestari \& Chariri, 2009). Penelitian (Yassin, 2017) Menyatakan bahwa Likuiditas berpengaruh terhadap Internet Financial Reporting (IFR). Berdasarkan uraian diatas, maka hipotesis yang dibangun dalam penelitian ini adalah:

\section{$\mathrm{H}_{3}$ : Likuiditas berpengaruh terhadap Internet Financial Reporting (IFR).}

Pengaruh Laverage terhadap Internet Financial Reporting (IFR)

Hasil penelitian yang dilakukan oleh (Mokhtar, 2017) menunjukkan bahwa perusahaan dengan tingkat leverage yang tinggi dapat menggunakan internet untuk memberikan informasi secara sukarela sehingga dapat mengurangi biaya agensi dan dapat memenuhi kewajiban mereka pada yanggal jatuh tempo. Penelitian yang dilakukan oleh Oyelere \& Kuruppu (2016), Diatmika \& Yadnyana (2017) dan Yassin (2017) memperoleh hasil bahwa Laverage berpengaruh terhadap Internet Financial Reporting (IFR). Berdasarkan uraian diatas, maka hipotesis yang dibangun dalam penelitian ini adalah:

\section{$\mathrm{H}_{4}$ : Leverage berpengaruh terhadap Internet Financial Reporting (IFR).}

\section{METODE PENELITIAN}

Jenis penelitian yang digunakan adalah penelitian kuantitatif. Sumber data dalam penelitian ini adalah data sekunder. Data diperoleh dari laporan keuangan yang diterbitkan di BEI atau di web perusahaan bersangkutan yang telah ditentukan sebagai sampel. Peneliti juga mencari referensi lain yang bersangkutan dengan rumusan masalah yang akan diteliti serta menggunakan jurnal sebagai acuan pengerjaan. Populasi dalam penelitian ini adalah perusahaan manufaktur sub sektor food and baverage yang terdaftar di BEI. Sampel yang diguakan dalam penelitian ini adalah perusahaan manufaktur sub sektor food and baverage yang terdaftar di BEI tahun 2015-2019 dengan teknik pengambilan sampel yang digunakan adalah purposive sampling, yaitu pemilihan sampel dengan kriteria tertentu.

Variabel dependen dalam penelitian ini adalah Internet Financial Reporting (IFR). Internet Financial Reporting merupakan media internet yang dapat digunakan oleh perusahaan dalam mempublikasikan laporan keuangan melalui website perusahaan yang telah diaktifkan. Laporan keuangan yang telah dterbitkan oleh perusahaan melalui website pribadi perusahaan tanpa menggunakan format tertentu, maka perusahaan tersebut telah menerapkan sistem IFR.

Dalam penelitian Internet Financial Reporting ini diukur menggunakan indeks pengungkapan IFR, yaitu suatu alat yang digunakan untuk mengukur kualitas laporan keuangan melalui website suatu perusahaan (Handayani \& Almilia, 2013). Menurut (Budisusetyo \& Almilia, 2008) indeks pengungkapan IFR yang digunakan merupakan pengembangan dari penelitian yang telah dilakukan oleh Cheng et. al. (2000). Dalam hal ini indeks pengungkapan IFR terdapat 4 komponen yaitu terdiri dari : isi (content), ketepatwaktuan (timeliness), pemanfaatan teknologi, dan dukungan pengguna (user support). Cara mengukur IFR dengan menggunakan rumus sebagai berikut :

$$
\text { IFR }=\frac{\text { Jumlah Skor Indeks yang Diungkapkan }}{\text { Total Skor Indeks Pengungkapan }}
$$

Variabel Independen

Ukuran perusahaan merupakan skala besar kecilnya perusahaan yang dapat diklasifikasikan berdasarkan berbagai cara anatara lain dengan ukuran pendapatan, total asset dan total ekuitas (Harahap, 2013). Pada penelitian kali ini ukuran perusahaan diukur berdasarkan dari total aset perusahaan. Adapun rumus Ukuran perusahaan adalah sebagai berikut :

$$
\text { SIZE }=\text { Ln (Total Aktiva) }
$$


Profitabilitas, Menurut (Kusumajaya, 2011) Profitabilitas adalah tingkat keuntungan bersih yang mampu diraih oleh perusahaan pada saat menjalankan operasinya. Dalam penelitian ini profitabilitas dihitung dengan menggunakan Return On Equity (ROE) yang merupakan perbandingan antara laba bersih dengan total ekuitas. Adapun rumus ROE adalah sebagai berikut:

$$
\text { ROE : } \frac{\text { Laba Bersih }}{\text { Total Ekuitas }}
$$

Likuiditas adalah kemampuan perusahaan untuk memenuhi kewajiban-kewajibannya yang segera harus dipenuhi (Pranoto, 2015). Likuditas dalam penelitian ini diukur dengan current ratio (CR). Adapun rumus CR adalah sebagai berikut :

$$
\text { CR : } \frac{\text { Aktiva lancar }}{\text { Hutang lancar }}
$$

Menurut (Harahap, 2013) leverage adalah rasio yang digunakan untuk mengukur sejauh mana aktiva perusahaan dibiayai oleh utang. Rasio ini dapat melihat seberapa jauh kemampuan perusahaan untuk membayar seluruh kewajibannya dengan modal perusahaan. Dalam penelitian ini leverage diproksikan menggunakan Debt to Equity Ratio (DER). Adapun rumus DER adalah sebagai berikut:

$$
\text { DER : } \frac{\text { Total hutang }}{\text { Total modal }}
$$

\section{Metode Analisis Data}

Metode pengolahan data yang digunakan adalah metode regresi linear berganda, yaitu untuk mengetahui pengaruh variabel bebas (X) terhadap variabel terikat (Y) (Sugiyono, 2016).

A. Statistik deskriptif digunakan untuk mendeskripsikan atau menggambarkan data yang telah terkumpul secara singkat variabel dalam penelitian melalui data sampel atau populasi (Sugiyono, 2017).

B. Uji Asumsi Klasik

\section{Uji Normalitas}

Uji normalitas dilakukan untuk mengetahui apakah data pada persamaan regresi yang dihasilkan berdistribusi normal atau berdistribusi tidak normal. Persamaan regresi dikatakan baik jika mempunyai data variabel bebas dan variabel terikat berdistribusi mendekati normal atau normal sama sekali (Ghozali, 2016). Uji normalitas data dapat dilakukan dengan menggunakan One Sample Kolmogorov Smirnov yaitu dengan ketentuan apabila nilai signifikan diatas 0,05 maka data terdistribusi normal. Sedangkan jika hasil One Sample Kolmogorov Smirnov menunjukkan nilai signifikan dibawah 0,05 maka data tidak terdistribusi normal.

2. Uji Heteroskedastisitas

Uji heteroskedastisitas bertujuan untuk menguji apakah dalam sebuah model regresi terjadi ketidaknyamanan varian dari residual satu pengamatan ke pengamatan lain. Jika varian berbeda, disebut heteroskedastisitas. Salah satu cara untuk mengetahui ada tidaknya heteroskedastisitas dalam suatu model regresi linier berganda adalah dengan melihat grafik sccatterplot atau nilai prediksi variabel terikat yaitu SRESID dengan residual error yaitu ZPRED. Jika tidak ada pola tertentu dan data menyebar diatas dan dibawah angka nol pada sumbu y, maka tidak terjadi heteroskedastisitas. Model yang baik adalah yang tidak terjadi heteroskedastisitas (Ghozali, 2016).

3. Uji Autokorelasi

Uji autokorelasi bertujuan menguji apakah dalam model regresi ditemukan adanya korelasi antara residual pada periode t dengan periode sebelumnya. Uji autokorelasi dapat dilakukan menggunakan Uji DurbinWatson (DW test). Nilai DW test yang berada diantara nilai du dan 4$\mathrm{dU}(\mathrm{dU}<\mathrm{d}<4-\mathrm{dU})$ menunjukkan model yang tidak terkena masalah autokorelasi (Ghozali, 2016).

4. Uji Multikolinieritas

Uji multikolinearitas bertujuan untuk menguji apakah model regresi ditemukan adanya korelasi antar variabel bebas (independen). Model regresi yang baik seharusnya tidak terjadi korelasi di antara variabel independen. Jika variabel independen saling berkorelasi, maka variabel-variabel ini tidak ortogonal. Variabel ortogonal adalah variabel independen yang nilai korelasi antar 
sesama variabel independen sama dengan nol (Ghozali, 2016). Untuk mengetahu gangguan multikolinearitas dapat dilihat dari :

a. Jika nilai VIF tidak lebih dari 10 dan nilai Tolerance tidak kurang dari 0,1 , maka model dapat dikatakan terbebas dari multikolinearitas.

b. Jika nilai VIF lebih dari 10 dan nilai Tolerance kurang dari 0,1, maka model dapat dikatakan terjadi multikolinearitas.

C. Uji Analisis Regresi Linear Berganda

1. Model Regresi

Persamaan regresi yang akan dianalisis dalam penelitian ini, yaitu sebagai berikut :

$Y=\alpha+\beta_{1} X_{1}+\beta_{2} X_{2}+\beta_{3} X_{3}+\beta_{4} X_{4}+e$

Keterangan :

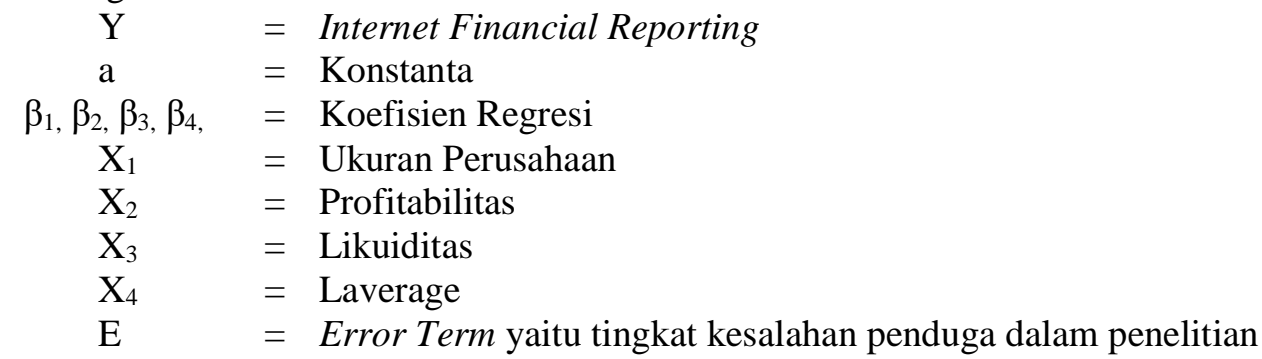

\section{PEMBAHASAN}

Hasil Pemilihan Sempel

Penelitian ini menggunakan sampel perusahaan manufaktur sub sektor food and baverage yang terdaftar di Bursa Efek Indonesia pada tahun 2015-2019 secara berturut-turut. Pengambilan sampel dilakukan dengan menggunakan teknik purposive sampling yaitu pengambilan sampel yang dilakukan berdasarkan kriteria yang telah ditetapkan oleh peneliti. Berikut ini adalah rincian pengambilan sampel penelitian :

Tabel 1

Pengambilan sampel penelitian

\begin{tabular}{|c|c|c|}
\hline No. & Kriteria Sempel & Jumlah \\
\hline 1 & $\begin{array}{l}\text { Perusahaan perusahaan manufaktur sub sektor food and baverage yang } \\
\text { terdaftar di BEI tahun 2015-2019. }\end{array}$ & 26 \\
\hline 2 & Perusahaan tidak yang memiliki website dan tidak dapat diakses & 0 \\
\hline 3 & $\begin{array}{l}\text { Perusahaan manufaktur sub sektor food and beverages yang menerbitkan } \\
\text { annual report periode } 2015-2019 \text {. }\end{array}$ & $(11)$ \\
\hline 4 & Perusahaan yang mengalami kerugian selama tahun pengamatan. & $(5)$ \\
\hline \multirow[t]{3}{*}{5} & Laporan keuangan yang menggunakan mata uang rupiah. & 0 \\
\hline & Jumlah sampel penelitian & $\mathbf{1 0}$ \\
\hline & Total Data ( 10 X 5 tahun periode penelitian) & $\mathbf{5 0}$ \\
\hline
\end{tabular}

\section{Sumber: Pengolahan Data}

\section{Uji Statistik Deskriptif}

Statistik deskriptif dilakukan untuk mengetahui gambaran data yang telah terkumpul secara singkat variabel-variabel dalam penelitian diantaranya jumlah data $(\mathrm{N})$, nilai rata-rata (mean), nilai minimum, nilai maksimum, dan standar deviasi (standar deviation) (Sugiyono, 2017). Hasil pengujian statistik deskriptif disajikan dalam tabel sebagai berikut :

Tabel 2

Statistik Deskriptif

\begin{tabular}{llllll}
\hline Variabel & $\mathrm{N}$ & Minimum & Maximum & Mean & Std. Deviation \\
\hline IFR & 50 & 0.555 & 0.740 & 0.64190 & 0.05269 \\
SIZE & 50 & 12.840 & 18.385 & 15.35654 & 1.51643 \\
ROE & 50 & 0.001 & 1.241 & 0.23970 & 0.28463 \\
CR & 50 & 0.584 & 8.638 & 2.61838 & 1.97561 \\
DER & 50 & 0.164 & 1.772 & 0.81230 & 0.45745 \\
\hline
\end{tabular}

Sumber : Pengolahan Data 
Berdasarkan hasil pengujian statistik deskritif diatas dapat diketahui bahwa dengan jumlah data penelitian sebanyak 50, diperoleh hasil sebagai berikut : Variabel dependen dalam penelitian ini yaitu IFR memiliki nilai minimum sebesar 0,555 , nilai maximum sebesar 0,740 nilai mean sebesar 15,35654 dan nilai std. Deviasi sebesar 0,05269. Variabel independen dalam penelitian ini yaitu SIZE memiliki nilai minimum sebesar 12,840, nilai maximum sebesar 18,385 nilai mean sebesar 0,64190 dan nilai std. Deviasi sebesar 1,51643. Variabel independen dalam penelitian ini yaitu ROE memiliki nilai minimum sebesar 0,001, nilai maximum sebesar 1,241, nilai mean sebesar 0,23970, dan nilai std. Deviasi sebesar 0,28463 . Variabel independen dalam penelitian ini yaitu CR memiliki nilai minimum sebesar 0,584, nilai maximum sebesar 8,638, nilai mean sebesar 2,61838, dan nilai std. Deviasi sebesar 1,97561. Variabel independen dalam penelitian ini yaitu DER memiliki nilai minimum sebesar 0,164 , nilai maximum sebesar 1,772, nilai mean sebesar 0,81230, dan nilai std. Deviasi sebesar 0,45745.

\section{Uji Asumsi Klasik \\ Uji Normalitas}

Tabel 3

Hasil Uji Normalitas

\begin{tabular}{llll}
\hline Variabel & $\begin{array}{l}\text { Asymp.Sig } \\
\text { (2-tailed) }\end{array}$ & Standar & Keterangan \\
\hline $\begin{array}{l}\text { Unstandardized } \\
\text { Residual }\end{array}$ & 0,200 & $>0,05$ & Data berdistribusi normal \\
\hline $\begin{array}{l}\text { Sumber : Pengolahan Data } \\
\text { Sula }\end{array}$
\end{tabular}

Sumber : Pengolahan Data

Berdasarkan tabel diatas hasil pengujian normalitas dengan uji Kolmogorov Smirnov, data dalam penelitian ini berdistribusi normal. Hasil output pengujian, besarnya nilai Asymp.Sig (2-tailed) pada variabel residual Unstandardized Residual adalah 0,200 nilai tersebut diatas signifikansi $=0,05$. Hal tersebut berarti dapat disimpulkan data pada penelitian ini terdistribusi secara normal.

Uji Multikolinieritas

Tabel 4

Hasil Uji Multikolinieritas

\begin{tabular}{llllll}
\hline Variabel & Tolerance & Standar & VIF & Standar & Keterangan \\
\hline SIZE & 0,874 & $>0,10$ & 1,144 & $<10$ & Tidak terdapat multikolieritas \\
ROE & 0,732 & $>0,10$ & 1,366 & $<10$ & Tidak terdapat multikolieritas \\
CR & 0,377 & $>0,10$ & 2,649 & $<10$ & Tidak terdapat multikolieritas \\
DER & 0,314 & $>0,10$ & 3,181 & $<10$ & Tidak terdapat multikolieritas \\
\hline
\end{tabular}

Sumber : Pengolahan Data

Berdasarkan pengujian multikolinieritas pada tabel diatas hasilnya menunjukkan bahwa semua varibel bebas pada penelitian ini mempunyai nilai Tolerance $>0,10$ dan memiliki nilai VIF $<10$. Sehingga dapat disimpulkan model regresi pada penelitian tidak terdapat multikolinieritas.

\section{Uji Autokorelasi}

Tabel 5

Hasil Uji Autokorelasi

\begin{tabular}{llllll}
\hline Durbin-Watson & dL & dU & 4-dL & 4-dU & Keterangan \\
\hline 1,728 & 1,3779 & 1,7210 & 2,6221 & 2,2790 & $\begin{array}{l}\text { Tidak terdapat } \\
\text { autokorelasi }\end{array}$ \\
\hline
\end{tabular}

Sumber : Pengolahan Data

Berdasarkan tabel hasil uji autokorelasi diatas dapat diketahui bahwa nilai DW dari hasil output pengujian adalah sebesar 1,728. Sedangkan nilai dL adalah sebesar 1,3779, nilai dU sebesar 1,7210 didapat dari tabel Durbin-Watson (DW) signifikansi 5\% dengan $\mathrm{k}=4$ (SIZE, ROE, CR, DER) dan $\mathrm{n}=$ 50 (banyaknya data penelitian). Sehingga dapat simpulkan bahwa dU $<$ DW $<4-\mathrm{dU}(1,7210<1,728<$ 2,2790 ) artinya antara variabel bebas dalam penelitian ini tidak terdapat autokorelasi. 


\section{Uji Heterokedastisitas}

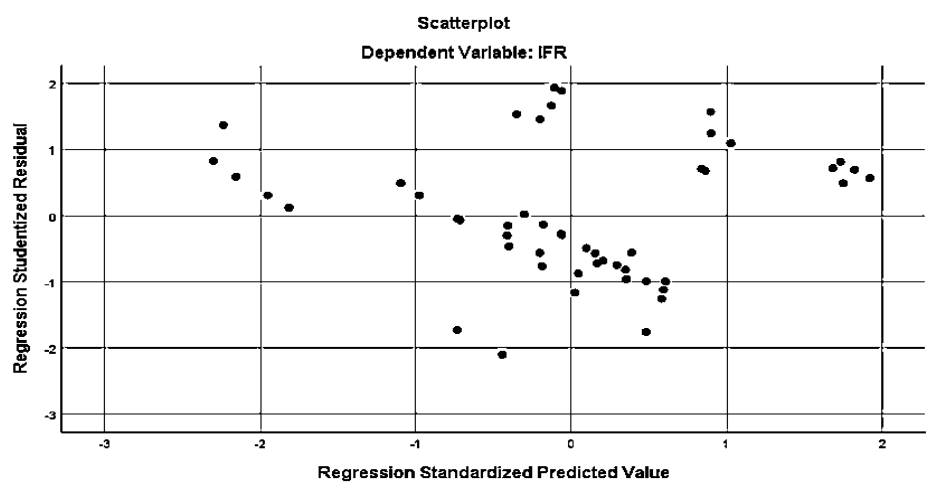

Gambar 2

Hasil Uji Heterokedastisitas

Hasil pengujian heteroskedastisitas yang telah dilakukan seperti pada gambar diatas menunjukkan bahwa dalam penelitian ini tidak terjadi heteroskedastisitas. Hal tersebut dapat dilihat pada titik-titik hasil pengolahan data menyebar diatas maupun dibawah titik Origin (angka 0) atau tidak memiliki suatu pola tertentu.

\section{Uji Hipotesis}

\section{Model Regresi}

Metode ini digunakan untuk mengukur hubungan antara lebih dari satu variabel independen (Y) dengan satu variabel dependen (X). Hasil model analisis regresi linier berganda disajikan dalam tabel sebagai berikut :

Tabel 6

Hasil Uji Model Regresi

\begin{tabular}{ll}
\hline Variabel & $\begin{array}{l}\text { Unstandardized Coefficients } \\
\text { B }\end{array}$ \\
\hline (Constant) & 0,425 \\
SIZE & 0,017 \\
ROE & $-0,061$ \\
CR & $-0,013$ \\
DER & 0,105 \\
\hline
\end{tabular}

Sumber : Pengolahan Data

Berdasarkan hasil pengujian pada tabel 6 dengan menggunakan program SPSS, maka didapat persamaan model regresi sebagai berikut :

$$
\mathrm{Y}=0,425 \mathrm{a}+0,017 \mathrm{X} 1-0,061 \mathrm{X} 2-0,013 \mathrm{X} 3+0,105 \mathrm{X} 4
$$

Persamaan regresi diatas memiliki pengertian sebagai berikut :Konstanta bernilai 0,425 (positif) maka dapat disimpulkan bahwa apabila semua variabel independen memiliki nilai 0 , maka IFR akan bertambah 0,425. Nilai koefisien regresi variabel Ukuran Perusahaan sebesar 0,017 (positif). artinya setiap menaikan 1 satuan Ukuran Perusahaan akan menaikkan IFR sebesar 0,017. Nilai koefisien regresi variabel Profitabilitas sebesar -0,061 (negatif). Artinya setiap kenaikan 1 satuan Profitabilitas akan menurunkan IFR sebesar 0.061. Nilai koefisien regresi variabel Liabilitas sebesar -0,013 (negatif). Artinya setiap kenaikan 1 satuan Liabilitas akan menaikkan IFR sebesar 0,013. Nilai koefisien regresi variable Laverage sebesar 0,105 (positif). Artinya setiap kenaikan 1 satuan Pertumbuhan penjualan akan meningkatkan struktur modal sebesar 0,105.

\section{Uji Kelayakan Model (Uji F)}

Tabel 7

Hasil Uji Kelayakan (Uji F)

\begin{tabular}{cccccc}
\hline Model & F hitung & F tabel & Sig & Standar & Keterangan \\
\hline 1 & 18,903 & $>2,58$ & 0,000 & $<0,05$ & Model Layak \\
\hline Sumber : Pengolahan Data
\end{tabular}


Berdasarkan hasil kelayakan model (uji F) pada tabel diatas menunjukkan bahwa variabel independen memiliki nilai $F_{\text {hitung }} 18,903$ signifikansi 0,000 , hal ini berarti bahwa nilai $F_{\text {hitung }}>F_{\text {tabel }}$ dan nilai signifikansi $<0,05$. Hal ini dapat disimpulkan bahwa secara bersama-sama variabel independen (Ukuran Perusahaan, Profitabilitas, Likuiditas, dan Leverage) berpengaruh terhadap variabel dependen (Internet Financial Reporting).

\section{Uji Hipotesis (Uji t)}

Uji t dilakukan untuk mengetahui pengaruh variabel independen (Ukuran Perusahaan, Profitabilitas, Liabilitas Dan Laverage) terhadap variabel dependen (Internet Financial Reporting).

Tabel 8

Hasil Uji Hipotesis (Uji t)

\begin{tabular}{cccccc}
\hline Hipotesis & t hitung & t tabel & Sig & Standar & Keterangan \\
\hline H1 & 5,005 & $>2,014$ & 0,000 & $<0,05$ & Diterima \\
H2 & $-3,075$ & $<-2,014$ & 0,004 & $<0,05$ & Diterima \\
H3 & $-3,198$ & $<-2,014$ & 0,003 & $<0,05$ & Diterima \\
H4 & 0,273 & $<2,014$ & 0,786 & $>0,05$ & Ditolak \\
\hline
\end{tabular}

Sumber : Pengolahan Data

Berdasarkan tabel di atas dapat diketahui bahwa variabel Ukuran Perusahaan, Profitabilitas, dan Liabilitas berpengaruh Internet Financial Reporting, Sedangkan variabel Laverage tidak berpengaruh terhadap Internet Financial Reporting.

\section{Uji Determinasi (Adjusted $\mathbf{R}^{2}$ )}

Tabel 9

Hasil Uji Koefisien Determinasi

\begin{tabular}{ccc}
\hline Model & Adjusted $\boldsymbol{R}$ Square & Keterangan \\
\hline 1 & 0,594 & Berpengaruh 59\% \\
\hline
\end{tabular}

\section{Sumber : Pengolahan Data}

Berdasarkan hasil uji koefisien determinasi pada tabel diatas, menunjukkan bahwa besarnya pengaruh variabel SIZE, ROE, CR, dan DER terhadap Internet Financial Reporting (IFR) sebesar 59\%. Hal tersebut ditunjukkan dari nilai Adjusted $R$ Square sebesar 0,594 sehingga $41 \%$ Internet Financial Reporting (IFR) dipengaruhi oleh variabel lain di luar model penelitian ini.

\section{KESIMPULAN}

Berdasarkan hasil penelitian yang telah dilakukan menunjukan bahwa variable Ukuran Perusahaan, Profitabilitas dan Likuiditas, berpengaruh terhadap Intern Financial Reporting (IFR), sedangkan variable Leverage tidak berpengaruh terhadap Intern Financial Reporting (IFR).

\section{KETERBATASAN}

Adapun keterbatasan dalam penelitian ini antara lain :

1. Populasi dalam penelitian ini hanya menggunakan perusahaan manufaktur sub sektor food and baverage yang terdaftar di BEI dengan periode pengamatan dari tahun 2015-2019.

2. Pada penelitian ini hanya mengunakan Ukuran Perusahaan, Profitabilitas, Likuiditas, dan Laverage sebagai variabel independennya.

3. Pengaruh variabel - variabel independent dalam penelitian ini sebesar $59 \%$ terhadap variabel dependen.

\section{SARAN}

Berdasarkan keterbatasan - keterbatasan yang telah di ungkapkan di atas, peneliti memiliki beberapa saran yang mungkin dapat menjadi bahan pertimbangan untuk melakukan penelitian kedepannya :

1. Bagi penelitian selanjutnya disarankan untuk menggunakan populasi seluruh perusahaan manufaktur yang terdaftar di BEI.

2. Penelitian selanjutnya disarankan menambah variabel independen lain yang di indikasi mempengaruhi Intern Financial Reporting (IFR), yaitu seperti Jenis Industri, Umur Listing, Jenis Auditor, dan Usia Perusahaan. Sehingga memperluas pengetahuan tentang faktor yang mempengaruhi Intern Financial Reporting (IFR). 


\section{REFERENSI}

Abdelsalam, O. H., El-Masry, \& Ahmed. (2008). "The Impact Of Board Independence And Ownership Structure On The Timeliness Of Corporate Internet Reporting Of Irish-Listed Companies". Managerial Finance, Vol. 34 No. 12, 2008 pp. 907-918.

Aboutera, L., \& Hussein, A. (2017). Determinants of Internet Financial Reporting by Egyptian. Research Journal of Finance and Accounting, 28-39.

Akbar, A. D. (2014). "Analisis Faktor Yang Memengaruhi Pengungkapan Laporan Perusahaan Melalui website". Diponegoro Journal of Accounting, Vol. 3, No. 3, pp. 1-12.

Budisusetyo, S., \& Almilia, L. (2008). The practice of financial disclosure on corporate website: Case study in Indonesia. Proceeding International Conference on Business \& Management, Universiti Brunei Darussalam.

Diatmika, I. P., \& Yadnyana, I. K. (2017). Pengungkapan Pelaporan Keuangan Melalui Website. EJurnal Akuntansi Universitas Udayana, 330-357.

Ettredge, M., Richardson, V. J., \& Scholz, S. (2001). The Presentation of Financial Information at Corporate Web Sites. International Journal of Accounting Information Systems 2, pp. 149-168.

Gat, F. (2016). Analisis Faktor-faktor Yang Mempengaruhi Pelaporan Keuangan Melalui Internet (Ifr) Pada Perusahaan Manufaktur Yang Terdaftar Di Bei. Financial Acounting, 657.042.

Ghozali, I. (2016). Aplikasi Analisis Multivariete Dengan Program IBM SPSS 23 (8 ed.).

Handayani, E., \& Almilia, L. (2013). Internet financial reporting: Studi komparasi perusahaan manufaktur yang terdaftar di bursa efek Indonesia dam bursa efek Malaysia. Jurnal Bisnis dan Ekonomi (JBE), Vol. 20, No. 2, 100-112. ISSN: 1412-3126.

Harahap, S. S. (2007). Analisis Kritis Laporan Keuangan. Jakarta: PT Raja Grafindo Persada.

Harahap, S. S. (2013). Analisis Kritis Atas Laporan Keuangan. Cetakan Kesebelas. Jakarta: Penerbit Rajawali Pers.

Heong Yap, K., \& Saleh, Z. (2011). Internet Financial Reporting In Malaysia : The Preparer's view. Asian Journal of Finance and Accounting, Vol. 3, No. 1, hlm 138-161.

Hermuningsih, S. (2013). Pengaruh Profitabilitas , Growth Opportunity , Sruktur Modal Terhadap Nilai Perusahaan Pada Perusahaan Publik di Indonesia. Buletin Ekonomi Moneter Dan Perbankan, 127-148.

Hidayah, N. (2017). Pengungkapan Informasi Keuangan Melalui Website Perusahaan Pada Perusahaan Food And Baverage Yang Terdaftar Di Bei. Skipsi.

Kusumajaya, D. (2011). Pengaruh Struktur Modal dan Pertumbuhan Perusahaan terhadap Profitabilitas dan Nilai Perusahaan pada Perusahaan Manufaktur di Bursa Efek Indonesia. Universitas Udayana, 1-132.

Kusumawardani, A. (2011). Analisis Faktor-Faktor yang Memengaruhi Pelaporan Keuangan Melalui Internet (Internet Financial Reporting) Dalam Website Perusahaan. h.1-5.

Lestari , H., \& Chariri, A. (2009). Analisis Faktor-faktor yang Mempengaruhi Pelaporan Keuangan Melalui Internet (Internet Financial Reporting) dalam Website Perusahaan. Jurnal Akuntansi. Universitas Diponegoro Semarang.

Mokhtar, E. S. (2017). Internet financial reporting determinants: a meta-analytic review. Journal of Financial Reporting and Accounting, Vol. 15 No. 1, pp. 116-154.

Oyelere, P., \& Kuruppu, N. (2016). Voluntary Internet Financial Reporting By Listed Companies In Emerging Economies: A Study Of Key Determinants In The United Arab Emirates. Asia Pacific Journal of Advanced Business and social studies, 161-176.

Oyelere, P., Laswad, F., \& R, F. (2003). Determinants of Internet Financial Reporting by New Zealand Companies. Journal of International Financial Management and Accounting 14, pp. 26-62.

Pranoto, K. P. (2015). Pengaruh Likuiditas, Profitabilitas, Ukuran Perusahaan, Jenis Industri, Leverage, Dan Umur Listing Terhadap Pelaporan Keuangan Melalui Internet Financial Reporting. Skripsi.

Prasetya, M., \& Irwandi, S. (2012). Faktor-faktor Yang Mempengaruhi Pelaporan Keuangan Melalui Internet (Internet Financial Reporting) Pada Perusahaan Manufaktur Di Bursa Efek Indonesia. The Indonesian Accounting Review, Volume 2, No. 2, pages 151 - 158.

Putri, M. A., \& Azizah, D. F. (2019). Pengaruh Ukuran Perusahaan, Leverage Dan Profitabilitas Terhadap Pelaporan Keuangan Melalui Internet/(Internet Financial Reporting). Jurnal Administrasi Bisnis (JAB), 205-213. 
Sugiyono. (2016). Metode Penelitian Kuantitatif, Kualitatif dan R\&D. Bandung: Alfabeta. Sugiyono. (2017). Metodologi Penelitian Bisnis. Bandung: Alfabeta.

Xiao, J. Z., Yang, H., \& C, W. C. (2004). The Determinants and Characteristics of Voluntary Internet Based Disclosures by Listed Chinese Companies. Journal of Accounting and Public Policy 23, pp. 191-225.

Yassin, M. (2017). The determinants of internet financial reporting in Jordan: financial versus corporate governance. Int. J. Business Information Systems, 526-556. 